\title{
ANALYSIS OF APPLICATION-BASED MOTORCYCLE SERVICE COST CALCULATION, CONSUMER BEHAVIOR, PRODUCER BEHAVIOR TOWARD GO-JEK DRIVER WELFARE IN DENPASAR CITY
}

\author{
Udiana Ni Wayan Pradnya Paramitha*, Yuliarmi Ni Nyoman \\ Faculty of Economics and Business, Udayana University, Bali, Indonesia \\ ${ }^{\star}$ E-mail: udianaanya@gmail.com
}

\begin{abstract}
Application-based transportation has become an important tool in society. Go-Jek is one of the application companies that are most in demand by the general public in big cities, one of which is Denpasar. Go-jek is able to contribute to the economy of Denpasar City. Go-jek drivers drive 12 percent of Denpasar's GDP. Go-jek has a good impact on the general public. There is unfair tariff competition between application companies and the number of online motorcycle taxi drivers is increasing because many people make online motorcycle taxi drivers a profession. The Decree of the Minister of Transportation issued KP 348 of 2019 concerning regulating the calculation of the cost of using motorbikes used for the benefit of the community which is carried out with an application aimed at application companies not conducting unfair tariff competition that affects the welfare of online motorcycle taxi drivers. The factors that influence the go-jek driver are consumer behavior and company behavior. This study aims to analyze the calculation of service fees, consumer behavior, company behavior towards go-jek drivers. This research was conducted in Denpasar City with a sample size of 120 respondents. Data collection was obtained from the results of distributing questionnaires using a Likert scale which was used to measure 12 indicators using the PLS SEM analysis method. The results of this study show 1) the calculation of service costs has a positive effect on consumer behavior. 2) Calculation of service fees has a positive effect on company behavior. 3) Calculation of service fees, consumer behavior, company behavior has a positive effect on go-jek drivers. 4) Consumer behavior and company behavior can indirectly mediate the calculation of service fees for go-jek drivers.
\end{abstract}

\section{KEY WORDS}

Calculation of service fees, Go-jek, welfare, corporate behavior, consumer behavior.

Go-Jek is the pioneer of online motorcycle taxis in Indonesia under PT. Go-Jek Indonesia was founded in 2010 by Nadiem Makarim where the company is engaged in online transportation services which connect drivers and consumers online. Go-jek consumers are dominated by people of productive age, high school education and above, from the middle and lower classes. The majority of Go-jek consumers feel satisfied, safe, and comfortable using Go-jek services (Demography Institute, 2019). According to the results of a study by the Demographic Institute of the University of Indonesia in 2019, 89 percent of consumers said that Go-Jek had a good impact on the general public. And if Go-Jek stops operating, as many as 78 percent agree it will be bad for the general public. Go-jek is committed to the welfare of its partners, drivers without exception. Welfare occurs when an individual's life is safe and happy because basic needs for nutrition, health, education, housing, and income can be met and protected from life-threatening risks (Suharto, 2006). The high consumer demand for Go-Jek services has encouraged high public demand to become Go-Jek drivers, because apart from getting income from fees (costs) paid by consumers, Go-Jek drivers also receive additional bonuses according to the performance of the Go-Jek drivers that are regulated. go-jek management where the value is significant enough to get additional value (Andrianus, 2017). Denpasar is a city that is the center of all economic activity and the first area to have Go-Jek services, both in delivering food, delivering goods, and delivering to their destination. According to the Demographic Institute of the Faculty of Economics and Business, University of Indonesia in collaboration with Go-Jek Indonesia, go-jek drivers 
contributed Rp 6.7 trillion or moved 12 percent of GRDP (Gross Regional Domestic Product) to the Denpasar city economy in 2019, if calculated using the economic value-added method Go-jek contributed 5.8 trillion Rupiah. Go-Jek drivers believe that they can make their family prosperous with Go-Jek with the benefits that come from being able to manage work time, understand more about using technology, and have more time with family. Go-Jek drivers' income increased by 70 percent after joining Go-Jek with an average income of Rp. $3,500,000$ to Rp. $6,000,000.00$ where the UMP in Denpasar is Rp. 2.4 million. More and more people are becoming go-jek drivers because they see opportunities to increase their income, which has an impact on the high demand to become go-jek drivers. However, if the demand to become a Go-Jek driver is not limited, it will boomerang for the Go-Jek driver itself, because it will become an access to supply that affects the welfare of the Go-Jek driver itself. The more Go-Jek drivers, the more difficult it is to find passengers or consumers. The competition between Go-Jek drivers is getting higher and the additional income bonuses received so far are increasingly difficult to obtain, especially since there are new regulations from Go-Jek management regarding the provision of additional bonuses which will ultimately reduce the welfare of Go-Jek drivers so that they are unable to meet family needs (Andrianus. 2017). The large number of people who make go-jek drivers a profession makes the government need to make policies to ensure the welfare of go-jek drivers themselves and can increase the use of online-based transportation. Where it is regulated in the ministry of transportation number KP 348 of 2019 concerning the calculation of the cost of using motorbikes used for the benefit of the community which is carried out with an application, where this is in the form of an indirect cost component which is a deduction from the applicator and direct costs which include gasoline costs, vehicle taxes, pulse fees, vehicle maintenance costs, and insurance. Tariff limit fees are divided into 3, namely: lower limit service fees, upper limit service fees, and minimum service fees. The implementation of the tariff limit covers three zones, namely: Zone I covering Sumatra, Java (without Jabotabek), and Bali. Then Zone II covers Jakarta, Bogor, Depok, Tangerang and Bekasi. Zone III includes: Kalimantan, Sulawesi, Nusa Tenggara Islands, Maluku Islands and Papua. This zone system is carried out because it is based on the level of community need for online motorcycle taxi services in each region. The tariff limit issued by the government is the net service rate for drivers, which means that the upper and lower limit drivers are obtained with a set fee, the tariff has not been added to the fees charged by the company to the driver of 20 percent and the fees charged by the company cannot be more than 20 percent. The Gojek company continues to create new strategies to compete, including creating strategies to increase customer satisfaction by innovating in improving the internal technology system, improving the quality of loyalty of all components. In facing the tariff limit policy from the government, Go-Jek provides compensation to its partners, namely online motorcycle taxis with a trip and bonus system, the trip system does not have special conditions, by only taking consumers to their destination with a 20 percent discount for each trip for the company, and compensation in the form of bonus points. where every time you close an online motorcycle taxi point, you will get an additional bonus. In addition, Go-Jek bonus points also apply a daily bonus.

\section{LITERATURE REVIEW}

\section{Definition of Go-Jek}

Go-Jek is a company that provides motorcycle taxi services using an online application and can serve anyone who needs its services. Go-Jek partners with experienced drivers in the Jakarta, Bali and Surabaya areas. In addition to being able to take someone to their destination, Go-Jek also provides goods delivery services, food delivery, shopping, and so on. Go-Jek was founded in 2010 and has now become a trending topic in any circles. Initially, Go-Jek only served via telephone calls, but in 2015 it began to develop and launched the Go-Jek application. This is done to make it easier for people to use Go-jek services (Citrayani, 2017). Go-jek services are available in various areas such as Greater Jakarta, Bali, Bandung, Surabaya, Makassar, Medan, Palembang, Semarang, Solo, 
Yogyakarta, Balikpapan, and Manado. As of June 206, the Go-Jek application has been downloaded nearly 10 million times on Google Play on the Android system (Setyawati, Devi 2017).

\section{Tariff Limit Policy Concept}

Carl J Federick as quoted by Leo Agustino (2008: 7) defines policy as a series of actions/activities proposed by a person, group or government in a certain environment where there are obstacles (difficulties) and opportunities for the implementation of the proposed policy in order to achieve certain goals. This opinion also shows that the idea of policy involving behavior that has a purpose and purpose is an important part of the definition of policy, because after all the policy must show what is actually done rather than what is proposed in some activities on a problem. Tariffs are an element of the marketing mix that are flexible, meaning they can change appropriately. This is of course different from product characteristics or commitment to distribution channels which cannot be changed or adjusted easily and precisely because they usually involve long-term decisions. Tariffs are the only element in the marketing mix that generates cash flow directly and also generates revenue. sales revenue. This is very different when compared to other elements in the marketing mix which generally incur costs (expenses). From the explanation above, it can be concluded that a company must set the right rate because price is the main element that can provide benefits for the company in the long and short term. However, tariffs will also cause difficulties and even bankruptcy for a company if it is not determined based on careful and correct considerations.

\section{Welfare Concept}

Based on the form of welfare, broadly, welfare consists of 2 types (Ishak, 2003) are Live Welfare, Direct welfare is an award in the form of salary, wages are paid regularly based on a fixed grace period and incentives are rewards given to motivate employees to have high work productivity. The last is Indirect Welfare, is a program of giving awards or rewards with wide variations as part of the profits of the organization or company (Nawawi, 2011). Indirect welfare is a complementary remuneration or allowance provided to employees based on the company's capabilities. So indirect compensation is remuneration provided in the form of employee services (Handoko, 2001).

\section{Income Concept}

Income is the remuneration received by a person for participation in the process of producing goods and services. This income is called income from work (labor income). Meanwhile, income that is not earned from work includes other people's gifts, money interest income, income from businesses run by other people, and room or house rental income. According to Kieso, Weygandt and Warfield (2011) which states that income is a gross inflow of economic benefits arising from the entity's normal activities during a period and these inflows will result in an increase in equity but not from investment contributions.

\section{Labor}

Manpower is every person who is able to carry out work, both inside and outside the employment relationship in order to produce services or goods to meet the needs of the community. So the workforce includes workers who work inside and outside the employment relationship, with the main means of production in the production process being their own workforce, both physical and mental energy. The structure of workers according to business fields at a macro level is a description of the economic characteristics of a region in terms of production with a large population, if it can be fostered and deployed as an effective workforce; it will be a large development capital and very profitable for development efforts in all fields. The large number of working age population is development capital.

\section{Consumer Satisfaction}

According to Kotler \& Keller (2009), satisfaction is a person's feelings of pleasure or disappointment that arise after comparing perceptions/impressions of the performance or 
results of a product and their expectations. Meanwhile, according to Rangkuti (2011), consumer satisfaction is a response or reaction to a discrepancy between the previous level of interest and the actual performance that is felt after use or use. Nasution, (2005) said that consumer satisfaction is highly dependent on consumer perceptions and expectations.

\section{Transportation}

The transportation sector is one sector that plays a very important role in overall economic development. The development of the transportation sector will directly reflect the ongoing growth of economic development; however, this sector is also known as one of the sectors that can have an impact on the environment in a large spatial and temporal scope. Transportation as a sector of urban activity is an activity that has the potential to change urban air quality. The development of transportation now brings the impact of a better life. Human power has shifted to mechanical power, making it easier for people to carry out activities even though the place is far away.

\section{Decree of the Minister of Transportation Number KP 348 of 2019}

The Minister of transportation issues a ministerial decree on "Calculation of the Cost of Motorcycle Services Used for the Interest of the Community Conducted by Application" which contains guidelines for calculating the cost of motorcycle services used for the benefit of the community which is carried out with an application consisting of Lower Limit Service Fee, Upper Limit Service Fee, and Minimum Service Fee. These costs are service costs that have received indirect cost discounts in the form of application rental fees. The minimum service fee as referred to is the fee that must be paid by passengers for the furthest distance of 4 (four) kilometers.

\section{Consumer Behavior}

According to Assael (2001) consumer decision making is the process of feeling and evaluating brand information, considering how alternative brands meet consumer needs and deciding on a brand. According to Assael (2001) there are 2 broad influences in determining consumer choice. The first influence is the individual consumer which needs, perceptions, brands, characteristics, and attitudes towards alternatives that influence brand choice. The second influence of consumer decision making is the environment. The consumer buying environment is described by culture (society norms and values), by sub-culture (part of society with different norms and values in certain life) and by face-to-face groups (friends, family members, and reference groups). When the consumer has made a decision, the postpurchase evaluation, described as feedback to the individual consumer, will take place.

\section{CONCEPTUAL FRAMEWORK}

The government's policy aims to limit the cost of tariffs because many people who make online motorcycle taxis a profession make the government need to make policies to ensure the go-jek drivers themselves and can increase the use of online-based transportation. Where the policy is regulated in the ministry of transportation number KP 348 of 2019 concerning the calculation of the cost of motorbikes used for the benefit of the community which is carried out by application, where the policy is in the form of an indirect cost component which is a deduction from the applicator and direct costs which include the cost of gasoline, vehicle taxes, credit fees, vehicle maintenance costs, and insurance.

Referring to the background of the problem, theoretical studies and empirical studies as previously described, in this study there is a conceptual framework for analyzing the impact of application-based motorcycle service cost calculation policies on Go-Jek (Go-Jek) drivers as follows: 


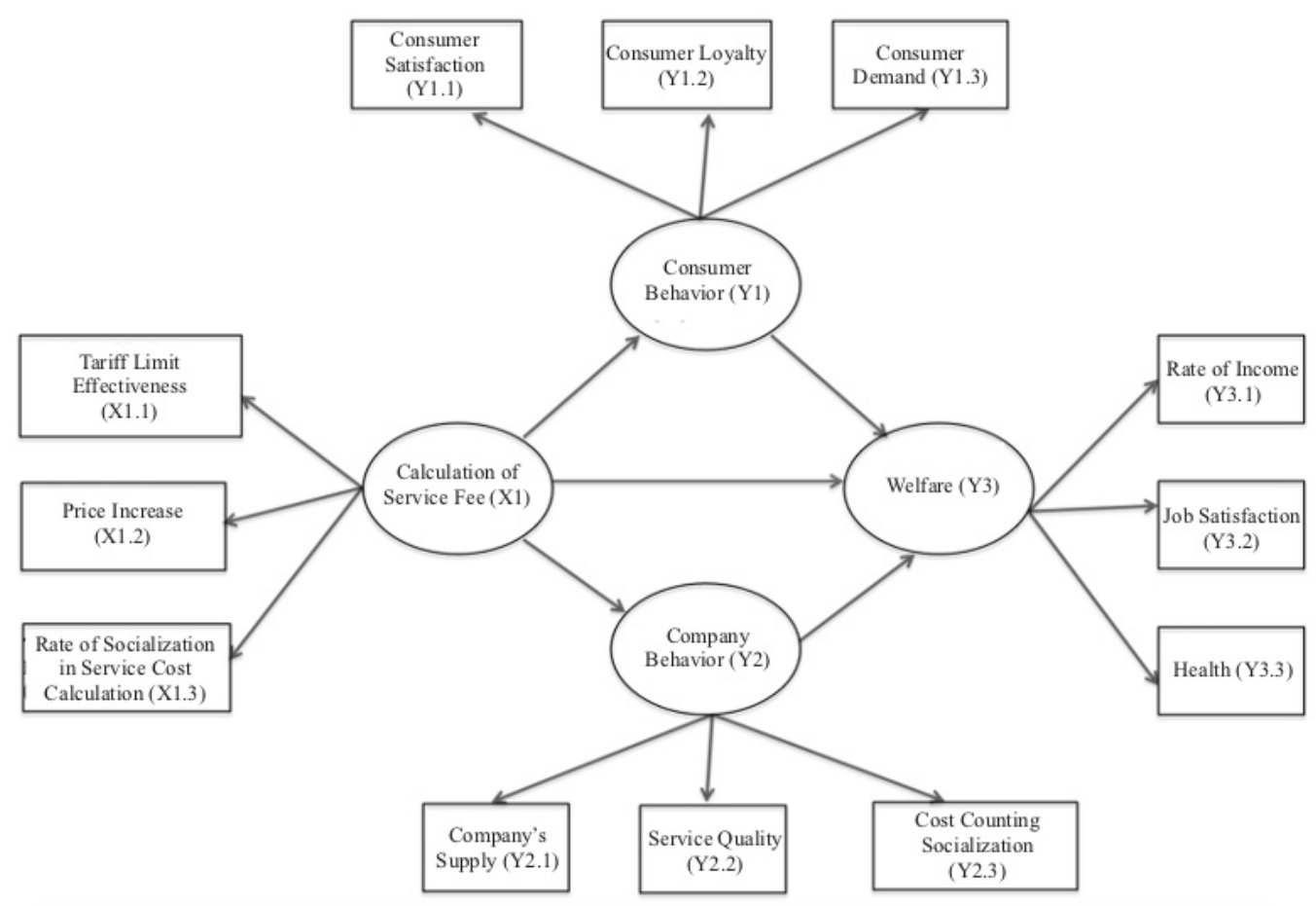

Figure 1 - Conceptual Framework

Research Hypothesis:

1) Calculation of service fees has a positive effect on consumer behavior;

2) Calculation of service fees has a positive effect on company behavior;

3) Calculation of service fees, consumer behavior, company behavior has a positive effect on go-jek drivers;

4) Consumer behavior and company behavior mediate the calculation of service fees on online welfare.

\section{METHODS OF RESEARCH}

The data collection method used in this research is observation, structured interviews and in-depth interviews. Furthermore, the data obtained in this study will be processed and analyzed and supported by theoretical studies and empirical studies in order to be able to prove the hypothesis and answer the problem formulation that has been collected through the development of instruments in the form of a list of questions that will be processed using descriptive analysis techniques and SEM structural equation analysis techniques. with partial least square (PLS) alternative. This analysis technique was chosen because it does not assume that the data must be in a certain measurement scale because it is based on nonparametric statistics and can also be used for a relatively small number of samples. The location of this research is in Denpasar City, Bali province. The object of this research is Service Fee Calculation Policy, Consumer Behavior, Company Behavior, and Go-Jek Drivers in Denpasar City. Service Fee Calculation Policy is measured by indicators of the effectiveness of the tariff limit policy, the level of influence of price increases, and the level of socialization of the calculation of service costs. Consumer behavior is measured by indicators of the level of consumer satisfaction, the level of consumer loyalty, the level of consumer demand. Company behavior is measured through indicators of company offerings, service quality, and socialization of service fee calculation policies. Finally, go-jek drivers in Denpasar City are measured by indicators of income level, job satisfaction level, and health. According to Sugiyono (2016: 85), Purpose random sampling is a sampling technique for data sources with certain considerations. This technique is used because the researcher selects a sample that has criteria that are in accordance with the phenomenon under study 
by setting certain considerations or criteria that must be met by the samples. Which. Used in this research. Based on these calculations, the number of respondents who ride motorcycle taxis online is as many as 120 samples.

\section{RESULTS AND DISCUSSION}

Validity test is used to determine whether a measurement instrument is valid or not. Validity is the degree to which a measuring instrument is able to measure what it is supposed to measure. The principle of validity contains two elements that cannot be separated, namely accuracy and thoroughness. A valid measuring instrument is not only able to express data precisely but also must provide a careful description (Sugiyono, 2018:172). Whether or not an instrument is valid can be seen from the value of the correlation coefficient between the item scores and the total score. Validity testing was carried out using Pearson product momment correlation with a correlation coefficient $>0.3$ (cut off $>30$ (Ghozali, 2011: 45). All statement items are seen in table 1 on the variables for calculating service costs, consumer behavior, company behavior, go drivers. -jek has been tested where to meet the validity requirements, the product moment coefficient has exceeded 0.3 then the statement items are valid. Questionnaires that have met the validity requirements are then retested using reliability tests. The value of an instrument is said to be reliable if Cronbach's alpha value is $>$ 0,60 . Reliability less than 0.6 is not good, while 0.7 is acceptable and above 0.8 is good Convergent validity can be seen from the Average Variance Extrated (AVE) in table 1 In the AVE study in table 1 all items above 0,5 , which means that the convergent validity conditions are met.Furthermore, to ensure that the model has no problems with discriminant validity, it is carried out in several ways. the comparison between the square root of variance extracted (AVE) values between the constructs and other constructs. Based on the square root value of the AVE, each value $(0.921 ; 0.913 ; 0.910 ; 0.926)$ is greater than the correlation of each construct. Thus it can be said that the model has no problems seen from the discriminant validity. Table 1 shows that the composite reliability coefficient is above the criteria limit of Wardana et al. (2016), which is $>0.6$ so there are no reliability problems. Based on table 1 $X 2$ and X3 have a value of variance inflation factor (VIF) $>5$, meaning that the constructs X2 and $X 3$ have a linear relationship with other constructs. While the rest have a value of variance inflation factor (VIF) $<5$, which means the construct does not have a linear relationship with other constructs.

Table 1 - Outer Loading Value

\begin{tabular}{lllllll}
\hline Variable & Instrument & Pearson Correlation & AVE & Composite Reliability & Cronbach's Alpha & VIF \\
\hline X1 & X1.1 & 0,770 & 0,849 & 0,944 & 0,909 & 2,205 \\
& X1.2 & 0,950 & & & & 12,885 \\
& X1.3 & 0,925 & & & 0,900 & 10,350 \\
Y1 & Y1.1 & 0,942 & 0,834 & 0,938 & & 4,091 \\
& Y1.2 & 0,937 & & & & 4,075 \\
& Y1.3 & 0,803 & & & & 2,086 \\
Y2 & Y2.1 & 0,889 & 0,828 & 0,935 & & 3,934 \\
& Y2.2 & 0,842 & & & & 2,170 \\
& Y2.3 & 0,936 & & & 0,916 & 3,211 \\
Y3 & Y3.1 & 0,942 & 0,857 & 0,947 & & 2,678 \\
& Y3.2 & 0,862 & & & & 4,242 \\
& Y3.3 & 0,968 & & & & \\
\hline
\end{tabular}

Before testing the hypothesis, it is necessary to evaluate the inner model which aims to determine the goodness of fit of the model using the R-square (R2) and Q-square (predictive relevance) methods. Q-square value $>0$ indicates the model has a good predictive relavance. The value of $Q$-square (predictive relavance) can be calculated as follows:

$$
\mathrm{Q} 2=1-\left(1-\mathrm{R}_{1}{ }_{1}\right)\left(1-\mathrm{R}_{2}{ }_{2}\right)\left(1-\mathrm{R}_{3}^{3}\right)=0,958 \sim 95 \%
$$


Calculation of Q-square (predictive relavance) yields a value of 95 percent which means that the model has a very good value. This means that 95 percent of the relationship between variables can be explained by the model. Based on the results of the above calculations R2 and Q2 then. can be continued with hypothesis testing analysis.

Table 2 - Path Coefficients

Mean, STDEV, T-Statistics, P-Values

\begin{tabular}{llllll}
\hline Path & Original Sample & Sample Mean & Standard Deviation & T-Statistics & $P$ Value \\
\hline$X_{1}-Y_{1}$ & 0,718 & 0,718 & 0,079 & 9,097 & 0,000 \\
$X_{1}-Y_{2}$ & 0,808 & 0,804 & 0,069 & 11,714 & 0,000 \\
$X_{1}-Y_{3}$ & 0,749 & 0,745 & 0,084 & 9,947 & 0,000 \\
$Y_{1}-Y_{3}$ & 0,396 & 0,354 & 0,178 & 2,227 & 0,026 \\
$Y_{2}-Y_{3}$ & 0,437 & 0,461 & 0,200 & 2,182 & 0,030 \\
\hline
\end{tabular}

Source: Research results, processed data (2021).

Table 2 shows that the relationship between service fee calculation variables (X1) on consumer behavior (Y1), service fee calculation variable (X1) on company behavior (Y2), service fee calculation variable (X1) on go-jek drivers (Y3), Variable the company's behavior (Y2) towards the go-jek driver (Y3) is positive and significant by comparing the P-Values smaller than alpha 0.05 .

Table 3 - Indirect Effects

Mean, STDEV, T-Statistics, P-Value

\begin{tabular}{llllll}
\hline Path & Original Sample (O) & Sample Mean (M) & Standard Deviation & T-Statistics (O/STDEV) & $P$ Value \\
\hline $\mathrm{X}_{1} \rightarrow \mathrm{Y}_{1} \rightarrow \mathrm{Y}_{3}$ & 0,284 & 0,243 & 0,114 & 2,499 & 0,013 \\
$\mathrm{X}_{1} \rightarrow \mathrm{Y}_{2} \rightarrow \mathrm{Y}_{3}$ & 0,353 & 0,371 & 0,167 & 2,119 & 0,035 \\
\hline
\end{tabular}

Source: Research results, processed data (2021).

Table 3 shows that there is an indirect relationship between the calculation of service fees for go-jek drivers mediated by consumer behavior, getting a t-count value of 2.499 with a $p$-value of 0.013 . This means that the consumer behavior variable is able to mediate the policy of calculating service costs on online welfare because the $p$ value $<0.05$. Table 3 also shows that there is an indirect relationship between the calculation of service fees for go-jek drivers mediated by the behavior of the company getting a t-count value of 2.119 with a $p$ value of 0.035 . This means that the company's behavior variable is able to mediate the calculation of service fees for go-jek drivers because p.value $<0.5$

\section{DISCUSSION OF RESULTS}

The calculation of service costs has a positive and significant effect on consumer behavior. The level of consumer loyalty to the use of the application since the calculation of service fees has continued to increase this is because since the calculation of service fees, consumers have become more frequent in getting promos and bonuses when using go-pay. Online motorcycle taxis also always get an average of 5 stars which is the highest star from consumers because on average they think the service from online motorcycle taxis is satisfactory and the application is easy to use. This is in line with adisantoso's research (2019) "Analysis of Minimum Tariff Changes and Competition for Promotion of Online Transportation Services in Consumer Purchasing Decisions" where changes in minimum tariffs do not disturb consumers. they pay according to what is in the application and most respondents say they are more comfortable using Go-Jek because they have often used it, by often using Go-Jek, they will often get promotions like what Maulida (19) got where she uses Go-Jek more often because she often gets discounted prices . According to Adisantoso (2019), although there is a minimum tariff, consumers feel that this must be balanced by promotions so that even if the price goes up, there will be a price cut according to the 
affordability of the price. Consumers also do not feel lost with the costs incurred because they feel the benefits provided by online services are in accordance with the price to be paid. They consider using online motorcycle taxi services to be more effective than other alternative modes.

Calculation of service fees has a positive and significant effect on company behavior. Since the calculation of service fees, the application company has received an increase in revenue, although it is not high. It is known that online motorcycle taxis through the Go-Jek event, namely Kopdar, are held every month and during this pandemic it was held virtually by the company in each regional branch. This is supported by Suryanti's research (2018) "Analysis of the Impact of Upper and Lower Limit Tariffs on Online Taxis on Business Continuity" there is a positive impact on Puspa Jaya's online transportation income at the upper and lower limit fares. It is proven that every 3 months the company's net income increases by 5 percent and this percentage is after the determination of the upper and lower tariff limits. According to Adisetiadi (2019) in his study "Transaction Cost Efficiency in Adjusting New Tariffs: Studying Go-Jek's Strategy Against New Regulations" Go-Jek's efforts to apply government regulations on limit policies In terms of tariffs, Go-Jek continues to innovate and look for the right solution so that companies can compete and not charge a maximum tariff of 20 percent in accordance with the limit provided by the government. Of course, by reducing transaction costs that arise as a result of current habit adjustments that are happening, such as pandemic conditions. One way is the Go-Jek effort in providing information about consumers, obtaining data about the condition of Go-Jek drivers and information. - other information needed to make business decisions by adjusting the new rates accordingly.

Calculation of service fees, producer behavior and consumer behavior have a positive and significant effect on go-jek drivers where the income level of online motorcycle taxis has increased since the calculation of service fees so that the level of job satisfaction of online motorcycle taxis and the level of consumer loyalty increase is also supported because during the pandemic Go-Jek also provides health insurance which can be claimed directly to the Go-Jek office in Denpasar. Since the government issued a calculation of the cost of services for online motorcycle taxis, they also feel safe and have a legal umbrella so that the company does not set a unilateral tariff limit where this is due to competition with the company next door to give the cheapest price, which causes Go-Jek's income to decrease but the working hours increase. According to Arifin (2020) in his study "The Influence of Working Hours, and Online Ojek Tariff Limit Policy on the Income Level of Grab Bike Drivers in Medan Tembung District" The tariff limit policy and income level also have a positive relationship where the lower the tariff offered, the greater the opportunity to earn. income. According to Wachid (2020), the new regulation, namely the $2019 \mathrm{KP}$, was made with the aim of maintaining the stability of business competition between online motorcycle taxi companies so that there is no price war between online motorcycle taxi managers. This new regulation is a legal umbrella, especially regarding the safety of drivers and passengers. The company's behavior towards go-jek drivers has a positive influence where this is in accordance with Adisetiadi's research (2019) in his study "Transaction Cost Efficiency in Adjusting New Tariffs: A Study of Go-Jek Strategies Against New Regulations" where Go-Jek's efforts to apply government regulations on tariff limit policies. Quoted from the official Go-Jek website on November 9, 2020, Go-Jek's Chief Commercial Officer, Antonie de Carbonel, said that Go-Jek introduced Goscreen as an outdoor advertising medium with the latest technology so as to make advertising more effective, optimal, and on target. GoScreen is a technology that can answer today's challenges. GoScreen is able to measure advertising performance based on location and time in full. GoScreen also has a positive social impact on online motorcycle taxis, where online motorcycle taxis get additional income from GoScreen by getting an additional $20 \%$ of their normal income. In an effort to implement the new tariff cost efficiency, GoScreen is the right answer because GoScreen advertising transaction fees are cheaper than other advertising and are more precise and measurable, so that when Go-Jek applies the tariff limits set by the government, Go-Jek is able to bring comfort to various partners and drivers. as a GoScreen additional income for the latest online motorcycle taxis. 
Producer behavior and consumer behavior can indirectly mediate the calculation of service fees for go-jek drivers, where it can be seen that the go-jek company provides rewards and bonuses to increase the productivity of online motorcycle taxis so that it has an additional impact on income for online motorcycle taxis since the calculation of service fees. The company also provides socialization and health insurance for online motorcycle taxis so that go-jek drivers are guaranteed. Consumer behavior is also indirectly able to mediate the calculation of service fees for go-jek drivers because since the calculation of service fees their income has increased, although not too much. However, since the pandemic, demand from consumers has increased rapidly and due to the calculation of the cost of online motorcycle taxi services, the income has also become greater. According to Adisetiadi's research (2019), Go-Jek responded to the calculation of service fees by establishing a new innovation, namely creating GoScreen which was able to increase revenue by 20 percent. And it can be seen that consumer behavior is indirectly able to mediate the tariff limit policy for Go-Jek drivers, supported by Adisantoso's research (2019) where many consumers know about the tariff limit policy but still use Go-Jek and pay according to the application because they are comfortable and accustomed to using Go-Jek. also supported by the theory of Kottler and Armstrong $(2019 ; 197)$ which states that the factors that influence consumer behavior consist of cultural, social, personal, and psychological.

\section{CONCLUSION}

The calculation of service costs has a positive and significant effect on consumer behavior variables, since the calculation of service costs consumers have become more frequent in getting promos and discounts. The calculation of service fees has a positive and significant effect on the company's behavior variables, since the calculation of the service fee, Go-Jek's income has increased, although not too high. Calculation of service fees, consumer behavior, company behavior has a positive and significant effect on go-jek drivers, the income level of online motorcycle taxis has increased since the establishment of service fee calculations so that the level of job satisfaction and the level of consumer loyalty increases. Consumer behavior and producer behavior can indirectly mediate the calculation of service fees for go-jek drivers, go-jek companies give rewards to online motorcycle taxis to increase online motorcycle taxi productivity so that online motorcycle taxi income increases, and consumer behavior since the cost calculation since the calculation policy service fees continue to use Go-Jek because they often get promos plus because of the pandemic, they use Go-Jek more often.

Based on the conclusions of the research above, the authors recommend It is better for consumers to be more socialized by the government about calculating service fees because there are still many consumers who know what service cost calculations are but do not understand what service fee calculations. The government should continue to supervise the company for the sake of the go-jek driver itself, even though the company has implemented a service fee calculation. For companies, it is better to be more active in discussing during the monthly kopdar to find out what the driver's complaints are so that drivers still feel involved in company decisions. For companies, it is better to give rewards not only in the form of points but can give priority to drivers who have continuously exceeded high points.

\section{REFERENCES}

1. Andrianus. 2017. Analisis Kesejahteraan Driver Go-jek di Kota Padang(Pendekatan Objektif dan Subjektif). Jurnal Dinamika Sosial Budaya, Vol 21, No.1

2. Aninditha, W. Arisanty, M. Rahmawati D. 2016. Analisis Penerapan Teknologi Komunikasi Tepat Guna pada Bisnis Transportasi OjekOnline (Studi pada Bisnis Go-jek dan Grab Bike dalam Penggunaan Teknologi Komunikasi Tepat Guna Untuk Mengembangkan Bisnis Transportasi). Prosiding Seminar Nasional INDOCOMPAC Universitas Bakrie. Jakarta. 2016

3. Bendesa, I. K.G 2017. Modul Analisis Faktor. Universitas Udayana 
4. Chin. W. W. 1998. The partial least swuares approach for structural equation modeling. in G. A. Marcoulides (Ed). Modern methods for business research (pp.295-236). London: Lawrence Erlbaum Associates.

5. Citrayani. Giri. Analisis Faktor - Faktor Yang Mempengaruhi Pendapatan Driver di Kota Denpasar. Bali. 2017

6. Dessler. Gary. 2015. Manajemen Sumber Daya Manusia. Jakarta: Salemba Empat.

7. Engel. F James. Roger D. Blackwell. Paul W. Miniard. 2004. Perilaku Konsumen. Jakarta: Binarupa Aksara.

8. Fery Andrianus, 2017. Analisis Kesejahteraan Driver Go-jek di Kota Padang (Pendekatan Objektif dan Subjektif). Dinamika Sosial Budaya, Vol 21

9. Fornell. C. and Lacker. D. F. 1981. Evaluating Structural Equatuion Models with Unobservable Variables and Measurement Error. Journal Of Marketing Research. 18(1).

10. Ghozali I. 2006. Aplikasi Analisis Multivariate dengan Program SPSS. Semarang: Badan Penerbit Universitas Diponegoro.

11. Giese. J.Land . J.A.Cote. 2000. Defining Customer Satisfaction. Academy of Marketing Science Review.

12. Guido Noto La Diega, Luce Jacovella. 2016. "Ubertrust: How Uber Represent Itself to Its Customer Through Its Legal and Non-Legal Documents". Journal of Civil and legal sciences. Queen Mary University of London, UK

13. Handoko. T Hani. 2001. Manajemen Personalia dan Sumber Daya Manusia. Yogyakarta: BPFE Yogyakarta.

14. Hasibuan Malayu S P. 1999. Organisasi \& Motivasi. Dasar Peningkatan Produktivitas. Jakarta: Bumi Aksara.

15. Hendrik. 2011. Analisis Pendapatan dan Tingkat Kesejahteraan Masyarakat Nelayan Danau Pulau Besar dan Danau Bawah di Kecamatan Dayun Kabupaten Siak, Propinsi Riau. Jurnal Perikanan dan Kelautan Vol.1 No. 16

16. Ishak, Arep, dan Hendri Tanjung, 2003. Manajemen Sumber Daya Manusia. Universitas Trisakti.

17. Jhohn Bolang, 2018. Comparative Analysis Of Extrinsic and Instrinsic Motivation Between Go-jek and Grab Driver in Manado. Faculty Economic and Business. University of Sam Ratulangi Manado.

18. Kardiman. 2003. Ekonomi. Jakarta: Yudhistira.

19. Kementrian Perhubungan Republik Indonesia. 2019.

20. Kieso dan Weygandt. 2011. Intermediete Accounting. 2011. Jakarta: Erlangga.

21. Kotler . Philip. dan Kevin Lane Keller. 2009. Manajemen Pemasaran. Edisi 13. Jilid satu. Erlangga: Jakarta.

22. Kotler. Philip. 2009. Manajemen Pemasaran. Jakarta: Erlangga.

23. Marsusanti. Eva, Susilawati, Rusli. Nugraha. Faktor - Faktor Yang Mempengaruhi Pendapatan Go-Jek. Jurnal Swabumi. Vol. 6 No. 2

24. Minto Purwo. 2000. Pelajaran Ekonomi. Yudhistira. Jakarta.

25. Mubyarto dan Sartono Kartodirdjo. 1998. Sumber Daya Manusia Peluang Kerja dan Kemiskinan. Yogyakarta: PT Tiara Wacana.

26. Nasution M. 2005. Total Quality Management. Jakarta: PT Gramedia Pustaka Utama

27. Nata Wirawan. 2002. Statistik 2 (Statistik Inferensia). Edisi Kedua. Denpasar Keraras Emas.

28. Nawawi. 2011. Manajemen Sumber Daya Manusia: Untuk Bisnis Yang Kompetitif. Gajah Mada University Press. Yogyakarta.

29. Rangkuti. Freddy. 2011. SWOT Balanced Scorecard. Jakarta: PT Gramedia Pustaka Umum.

30. Rosni. 2017. Analisis Tingkat Kesejahteraan Masyarakat Nelayan Di Desa Dahari Selebar Kecamatan Talawi Kabupaten Batubara. Jurnal Feografi Vol.9 No.1

31. Samuelson dan Nordhaus. 2002. Ilmu Makro ekonomi. Jakarta: media Global Edukasi.

32. Sina Shokoohyar, 2018. Ride Sharing Platforms From Driver's Perspective: Evidence From Uber and Lyft Drivers". Saint Joseph University, United States. 
33. Sri Darma, Wicaksono, Gede Sanica, Abiyasa. 2019. Faktor Kompensasi dan Strategi Go-Jek Dalam Meningkatkan Kepuasan Kerja Para Driver. Vol.6 No.3 Universitas Sam Ratulangi.

34. Sudarmanto. Gunawan R. 2005. Analisis Regresi Linear Berganda Dengan SPSS. Yogyakarta: Graha Ilmu.

35. Sugiono. Suwitho. Suhermin. Penetuan Brand Awereness Pada Aplikasi Ojek Online (GO-JEK). Jurnal Magister Manajemen Unoversitas Mataram. Vol.3 No.3

36. Sugiyono. 2008. Metode Penelitian Bisnis.Alfabeta. Bandung

37. Sugiyono. 2012. Metode Penelitian Bisnis. Bandung: CV. Alfabeta

38. Suharto, Edi. 2006. Peta dan Dinamika Welfare State din Beberapa Negara: Pelajaran apa yang bisa dipetik untuk membangun Indonesia

39. Sukirno, Sadono. 2001. Pengantar Teori Mikro Ekonomi. Jakarta: PT. Raja Grafindo Persada.

40. Suprihanto John. Dkk. 2003. Perilaku Organisasional. Yogyakarta: Sekolah Tinggi Ilmu Ekonomi YKPN.

41. Suryanti. Tirani. 2018. Analisis Dampak Besaran Tarif Batas Atas dan Batas Bawah Pada Taksi Online Terhadap Keberlangsungan Usaha Dalam Perspektif Islam. Fakultas Ekonomi dan Bisnis Islam. Universitas Islam Negeri. 2018

42. Swastika, Mega. 2017. Fungsionalitas Konflik Go-Jek: Studi Fenomenologi Terhadap Konflik Pengemudi Go-Jek di Kota Kediri.

43. Todaro, Michael P. 2000. Pembangunan Ekonomi diDunia Ketiga Jilid I.Edisi Ketujuh. Jakarta : Erlangga.

44. Werts. C.E; Linn, R.L dan Joreskog.K.G. 1974. "Intraclass Reliability Estimates: Testing Structural Assumption". Educational and Psychological Measurement. 34. pp.25-33.

45. Wilkie. L. 1994. Customer Behavior. New York: John wiley and sons. 